\title{
PENCEGAHAN BROWNING FASE INISIASI KALUS PADA KULTUR MIDRIB DAUN KLON KARET (HEVEA BRASILIENSIS MUELL. ARG) PB 330
}

\author{
Browning Prevention on Callus Initiation Phase on Leaf Midrib of PB 330 \\ Rubber Clone Culture (Hevea brasiliensis Muell. Arg) \\ Lestari ADMOJO $^{\left.1^{*}\right)}$ dan Ari INDRIANTO ${ }^{2)}$ \\ ${ }^{1 *}$ Balai Penelitian Getas, Pusat Penelitian Karet \\ Jl. Pattimura KM 6 Salatiga Jawa Tengah \\ Email: tariadmojo@balitgetas.co.id \\ ${ }^{2)}$ Fakultas Biologi, Universitas Gadjah Mada \\ Jl. Teknika Selatan, Sekip Utara, Yogyakarta
}

Diterima : 6 Januari 2016 / Direvisi : 30 Mei 2016 / Disetujui : 24 Juni 2016

\begin{abstract}
Tissue culture is one of new efforts to improve of rubber Hevea brasiliensis Muell. Arg clonal propagation. Nevertheless, one of the major problems is lethal browning on callus initiation. Browning caused by some phenolic compound which accumulated during wounding. This experiment was conducted to investigate the effect of antioxidant ascorbic acid, activated charcoal+sucrose, repeated culture, in combination under the dark and light culture incubations in controlling lethal browning in in-vitro culture of rubber clone PB 330 using midrib leaf explant. Explant was planted on callus initiation medium $M S+2,4-D 5 \mathrm{ppm}$ using 10 bottles as replication, were planted in each bottle. The observation covered the early time of browning initiation, intensity of browning, and number of explants browning up to 35 Day After Culture (DAC). Data were analyzed by Analysis of Variance of Factorial Design and significant different among treatment were compared by Duncan Multiple Range Test. The results of the current study revealed that the best treatment was soaked on $100 \mathrm{mg} / \mathrm{L}$ ascorbic acid soluble sterile treatment by 30 minutes before planted on medium and culture placed under dark condition, showed browning intensity of explants was significantly controlled down to $7.5 \%$ and also number of browning explants reduced up to $30 \%$.
\end{abstract}

Keywords: Rubber clone; Hevea brasiliensis; PB 330; browning; ascorbic acid
Abstrak

Perbaikan teknik perbanyakan dan mutu bibit klonal karet (Hevea brasiliensis Muell. Arg) dapat dilakukan melalui teknik kultur jaringan. Kendala teknik tersebut diantaranya masih tingginya intensitas browning pada tahap inisiasi kalus. Browning umumnya disebabkan oleh senyawa fenolik yang biasanya muncul dan terakumulasi ketika eksplan dilukai. Penelitian ini bertujuan mengetahui metode eliminasi browning yang efektif diantara perlakuan perendaman eksplan dalam asam askorbat, arang aktif+sukrosa, subkultur berulang yang diinkubasi dalam ruang gelap dan terang. Bahan eksplan yang digunakan adalah eksplan midrib daun klon karet PB 330 yang ditanam pada media induksi kalus MS+2,4-D 5 ppm. Masing-masing menggunakan 10 botol sebagai ulangan dan ditanam sebanyak 2 eksplan per botol. Pengamatan meliputi waktu awal browning, waktu rata-rata eksplan mengalami browning, intensitas browning dan jumlah eksplan browning hingga 35 hari setelah tanam (HST). Data dari 10 eksplan untuk masing-masing perlakuan selanjutnya dianalisis dengan analisis ragam dari Rancangan Faktorial dan uji lanjut dengan Duncan Multiple Range Test untuk data yang berbeda nyata. Hasil percobaan menunjukkan bahwa perendaman eksplan dalam $100 \mathrm{mg} / \mathrm{L}$ asam askorbat steril selama 30 menit, yang diinkubasi dalam ruang gelap efektif menurunkan intensitas browning hingga $7,5 \%$ dengan jumlah 
eksplan yang mengalami browning dapat ditekan hingga $30 \%$.

Kata kunci: Klon karet; Hevea brasiliensis; PB 330; browning; asam askorbat

\section{PENDAHULUAN}

Salah satu upaya perbaikan mutu bibit klonal karet (Hevea brasiliensis Muell. Arg) yang dapat dilakukan adalah melalui teknik kultur jaringan. Teknik tersebut membuka peluang untuk mengatasi beberapa persoalan mutu bibit yang diperbanyak secara konvensional. Persoalan tersebut antara lain menurunnya juvenilitas bibit dan inkompatibilitas yang mungkin terjadi antara batang atas dan batang bawah. Sejauh ini, masih terdapat beberapa kendala dalam teknik kultur jaringan yang perlu diatasi. Salah satu kendala yang dihadapi adalah sulitnya meregenerasi kalus dari eksplan tanaman klonal karena masih tingginya tingkat browning pada fase induksi kalus. Browning (pencoklatan) pada jaringan merupakan salah satu permasalahan yang sering terjadi pada kultur tanaman berkayu. Browning umumnya disebabkan oleh senyawa fenolik yang biasanya muncul dan terakumulasi ketika eksplan dilukai, yang biasanya disebabkan oleh aktivasi dari enzim Polyphenol oxidase (PPO). Pelukaan organ dapat menyebabkan terjadinya ketidakseimbangan metabolisme dari ROS (Reactive Oxygen Species), peroksidasi pada membran lipid, dan kehilangan integritas membran sel yang dapat memicu over akumulasi dari senyawa fenolik dan menyebabkan terjadinya browning ( $\mathrm{Ru}$, Lai, $\mathrm{Xu}, \& \mathrm{Li}, 2013)$. PPO dan peroxidase (POD) diketahui banyak ditemukan pada family Euphorbiaceae, Moraceae, dan Anacardiaceae yang antara lain berhubungan dengan kandungan getah (lateks) yang tinggi (John, Bhat, \& Prasada Rao, 2003). Umumnya, pencoklatan merupakan hasil dari interaksi antara aktivitas enzim PPO dan kandungan polifenol. Seperti diketahui, perubahan permeabilitas membran menyebabkan pelepasan enzim dan substrat pada sitosol yang memicu pigmentasi atau pencoklatan (Mellidou et al., 2014).
Upaya mengatasi browning pada kultur tanaman berkayu dapat dilakukan antara lain dengan penambahan senyawa antioksidan seperti asam askorbat, modifikasi lingkungan kultur dengan menempatkan dalam ruang gelap total, subkultur berulang atau pencelupan dalam cairan seperti arang aktif dan sukrosa. Pada beberapa kasus, satu jenis perlakuan pencegahan browning seringkali tidak cukup efektif sehingga kadang kala kombinasi perlakuan perlu dilakukan. Pada tanaman Sideritis trojana Bornm., penambahan antioksidan $100 \mathrm{mg} / \mathrm{L}$ asam askorbat dan $50 \mathrm{mg} / \mathrm{L}$ asam sitrat pada media, penyimpanan kultur dalam ruang gelap dan subkultur secara cepat setiap minggu lebih efektif dalam mencegah browning dibandingkan dengan perlakuan tunggal (Corduk \& Aki, 2011). Pada tanaman pir (Pyrus communis L.), kombinasi antioksidan $(100 \mathrm{mg} / \mathrm{L}$ asam askorbat dan $150 \mathrm{mg} / \mathrm{L}$ asam sitrat) sebagai pra perlakukan selama 1 jam + Polyvinyl pyrrlidone (PVP) $160 \mathrm{mg} / \mathrm{L}$ + arang aktif 200 $\mathrm{mg} / \mathrm{L}$ yang ditambahkan pada media signifikan mengurangi nekrosis dan browning (Esmail et al., 2014). Pada tanaman pisang spesies grand naine yang bergetah, browning mampu ditekan dengan penambahan asam askorbat dengan kombinasi asam sitrat, arang aktif, cysteine, dan sari jahe yang diberikan pada saat pra perlakuan (Morfeine, 2013).

Penelitian ini bertujuan untuk mengetahui metode paling efektif dalam mencegah browning fase induksi kalus pada kultur midrib (bagian pertulangan) daun klon karet PB 330.

\section{BAHAN DAN METODE}

Penelitian dilakukan di Laboratorium Bioteknologi, Fakultas Biologi Universitas Gadjah Mada Yogyakarta, sejak Juni hingga November 2014. Bahan dan metode yang digunakan dalam penelitian meliputi :

\section{Bahan tanam dan sumber eksplan}

Bahan tanam menggunakan bibit polibag klon karet PB 330 pada stadia 1-2 payung daun. Bagian daun diambil dari 
tunas pada usia sekitar 5-8 hari setelah flush. Daun yang diambil adalah yang telah berwarna hijau segar (tidak lagi berwarna coklat seperti fase awal flush) dan sehat. Bibit klon karet PB 330 diperoleh dari Balai Penelitian Getas, Salatiga, Jawa Tengah.

\section{Penyiapan eksplan}

Daun yang telah diambil sebagai sumber eksplan selanjutnya disiapkan di Laboratorium. Pra sterilisasi dilakukan dengan pencucian daun dalam detergen cair di bawah air mengalir. Setelah bersih, daun dipotong sekitar 3-5 cm dan diletakkan di dalam erlenmeyer kemudian disterilisasi di dalam Laminar Air Flow. Daun disterilisasi dengan merendam dalam alkohol 70\%, digojog 2-3 menit, kemudian dibilas dengan akuades steril 2 kali. Selanjutnya daun direndam dalam Clorox 2,25\%, dikocok selama 2-3 menit dan dibilas dengan akuades steril 3 kali. Sebelum ditanam, daun dipotong di bagian tepi (hingga tersisa bagian midrib atau pertulangannya daunnya) sepanjang $1 \times 1,5 \mathrm{~cm}$.

\section{Perlakuan pencegahan browning}

Pada perlakuan perendaman eksplan, eksplan direndam dalam asam askorbat 100 $\mathrm{mg} / \mathrm{L}$ steril dan arang aktif $2 \mathrm{~g} / \mathrm{L}+$ sukrosa 8 $\mathrm{g} / \mathrm{L}$ steril dan digoyang perlahan selama 30 menit, setelah itu langsung ditanam dalam media. Larutan asam askorbat disterilkan dengan milipore filter $0,2 \mu$ dan larutan sukrosa+arang aktif di dalam autoklaf sebelum digunakan. Setelah eksplan ditanam dalam media, selanjutnya diinkubasi pada kondisi gelap dan di bawah penyinaran. Perlakuan subkultur berulang dengan memindah tanam eksplan baik eksplan dengan perlakuan perendaman asam askorbat atau arang aktif+sukrosa maupun tanpa perlakuan perendaman setiap 7 hari sebanyak 2 kali pindah tanam dalam media yang sama. Asam askorbat dan arang aktif diperoleh dari Merck Jerman. Matriks kombinasi perlakuan disajikan dalam Tabel 1.

\section{Kondisi kultur dan media tanam}

Kultur selanjutnya ditempatkan pada dua kondisi yaitu ruang gelap dan terang. Ruang terang dengan menempatkan kultur di bawah penyinaran lampu TL 1000 lux, suhu $25^{\circ} \mathrm{C}$ dan kelembaban 60-70\%. Media tanam menggunakan media MS (Murashige \& Skoog) dengan penambahan auksin 2,4-D 5 ppm (2,4-Diclorophenoxy acetic acid). pH medium sekitar $5,7-5,8$ sebelum diautoklaf pada suhu $121^{\circ} \mathrm{C}$ pada tekanan 1 atm. Auksin diperoleh dari Merck Jerman.

\section{Rancangan percobaan dan pengamatan}

Percobaan disusun dengan Rancangan Faktorial dengan 10 botol sebagai ulangan, tiap botol ditanam sebanyak 2 eksplan. Pengamatan dilakukan terhadap waktu mulai terjadinya browning, jumlah eksplan yang mengalami browning, intensitas browning dan waktu terjadinya lebih dari $50 \%$ total eksplan mengalami browning yang diamati hingga 35 HST (hari setelah tanam). Intensitas browning diukur berdasarkan kategori dalam Tabel 2. Perlakuan subkultur berulang diamati setelah subkultur pertama atau 7 HST. Data intensitas browning dianalisis dengan analisis ragam dari Rancangan Faktorial dan uji lanjut dengan Duncan Multiple Range Test (DMRT) untuk data yang berbeda nyata pada taraf nyata 5\% menggunakan software SAS 9.1 .

Tabel 1. Kombinasi perlakuan pencegahanbrowning fase induksi kalus Table 1. Combination of browning treatments on callus induction phase

\begin{tabular}{|c|c|c|}
\hline \multirow{2}{*}{$\begin{array}{l}\text { Perlakuan } \\
\text { Treatment }\end{array}$} & \multicolumn{2}{|c|}{$\begin{array}{c}\text { Kondisi inkubasi } \\
\text { Incubation }\end{array}$} \\
\hline & $\begin{array}{c}\text { Terang } \\
\text { Light }\end{array}$ & $\begin{array}{l}\text { Gelap } \\
\text { Dark }\end{array}$ \\
\hline Tanpa perlakuan (kontrol) & B1 & B2 \\
\hline Rendam asam askorbat & B3 & B4 \\
\hline Rendam sukrosa+arang aktif & B5 & B6 \\
\hline Subkultur berulang & B7 & B8 \\
\hline Subkultur berulang+ rendam asam askorbat & - & B9 \\
\hline Subkultur berulang+rendam (sukrosa+arang aktif) & - & $\mathrm{B} 10$ \\
\hline
\end{tabular}


Tabel 2. Penilaian intensitas browning

Table 2. Scoring of browning intensity

\begin{tabular}{ccc}
\hline No. & $\begin{array}{c}\text { Skoring } \\
\text { Scoring }\end{array}$ & $\begin{array}{c}\text { Keterangan } \\
\text { Remarks }\end{array}$ \\
\hline 1. & $0-0,24$ & $0-<1 / 4$ bagian eksplan mengalami browning \\
2. & $0,25-0,49$ & $1 / 4-<1 / 2$ bagian eksplan mengalami browning \\
3. & $0,50-0,74$ & $1 / 2-<3 / 4$ bagian eksplan mengalami browning \\
4. & $0,75-0,99$ & $3 / 4-<1$ bagian eksplan mengalami browning \\
5. & 1,00 & Seluruh bagian eksplan mengalami browning \\
\hline
\end{tabular}

\section{HASIL DAN PEMBAHASAN}

Secara umum seluruh perlakuan menunjukkan hasil yang berbeda nyata dengan kontrol, baik kontrol terang maupun kontrol gelap. Hasil pengamatan yang dilakukan hingga 35 hari setelah tanam (HST) disajikan dalam Tabel 3. Waktu awal kemunculan browning paling lama terjadi pada perlakuan perendaman eksplan dalam media sukrosa+arang aktif yang diinkubasi di ruang gelap dan perendaman eksplan dalam asam askorbat yang diinkubasi di ruang gelap, yaitu berturut-turut pada 19 dan 17 HST, nilai ini lebih baik dibanding kontrol gelap dan kontrol terang. Waktu $>50 \%$ eksplan mengalami browning menunjukkan perlakuan subkultur berulang yang diinkubasi di ruang terang menunjukkan waktu yang lebih cepat, yaitu 13 HST dan nilai ini masih lebih baik dibanding dengan kontrol gelap dan kontrol terang yang masing-masing terjadi pada 7 HST. Perlakuan perendaman eksplan dalam asam askorbat yang diinkubasi di ruang gelap dan kombinasinya dengan subkultur

Tabel 3. Pengaruh beberapa perlakuan terhadap terjadinya browning

Table 3. Effect of each treatment on browning of explants.

\begin{tabular}{|c|c|c|c|c|c|c|c|}
\hline \multirow{2}{*}{$\begin{array}{l}\text { Kode } \\
\text { Code }\end{array}$} & \multirow{2}{*}{$\begin{array}{l}\text { Perlakuan } \\
\text { Treatments }\end{array}$} & \multirow{2}{*}{$\begin{array}{l}\text { Jumlah } \\
\text { eksplan } \\
\text { Number } \\
\text { of } \\
\text { explants }\end{array}$} & \multirow{2}{*}{$\begin{array}{l}\text { Waktu } \\
\text { awal } \\
\text { browning } \\
\text { (HST) } \\
\text { Early time } \\
\quad \text { of } \\
\text { browning } \\
\text { (DAC) }\end{array}$} & \multirow{2}{*}{$\begin{array}{c}\text { Persentase } \\
\text { intensitas } \\
\text { browning } \\
\text { Percentage of } \\
\text { browning } \\
\text { intensity } \\
\text { (\%) }\end{array}$} & \multirow{2}{*}{$\begin{array}{c}\text { Jumlah } \\
\text { eksplan } \\
\text { browning } \\
\text { Number of } \\
\text { browning } \\
\text { explants }\end{array}$} & \multirow{2}{*}{$\begin{array}{l}\text { Persentase } \\
\text { jumlah } \\
\text { eksplan } \\
\text { browning } \\
\text { Percentage } \\
\text { of browning } \\
\text { explants } \\
\text { (\%) }\end{array}$} & \multirow{2}{*}{$\begin{array}{l}\text { Waktu } \\
>50 \% \\
\text { eksplan } \\
\text { browning } \\
\text { (HST) } \\
\\
\text { Time of } \\
>50 \% \\
\text { explants } \\
\text { browning }\end{array}$} \\
\hline & & & & & & & \\
\hline KT & Kontrol terang & 20 & 3 & $95,0 \mathrm{a} \pm 10,5$ & 20 & 100 & 7 \\
\hline KG & Kontrol gelap & 20 & 5 & $90,0 \mathrm{a} \pm 10,4$ & 20 & 100 & 7 \\
\hline AA-T & $\begin{array}{l}\text { Rendam asam } \\
\text { askorbat - terang }\end{array}$ & 20 & 12 & $45,0^{b} \pm 27,6$ & 14 & 70 & 35 \\
\hline $\mathrm{AA}-\mathrm{G}$ & $\begin{array}{l}\text { Rendam asam } \\
\text { askorbat - gelap }\end{array}$ & 20 & 17 & $7,5^{c} \pm 2,6$ & 6 & 30 & - \\
\hline SA-T & $\begin{array}{l}\text { Rendam (sukrosa+ } \\
\text { arang aktif) - terang }\end{array}$ & 20 & 15 & $52,5^{b} \pm 36,1$ & 14 & 70 & 22 \\
\hline SA-G & $\begin{array}{l}\text { Rendam (sukrosa+ } \\
\text { arang aktif) - gelap }\end{array}$ & 20 & 19 & $45,0^{\mathrm{b}} \pm 31,4$ & 12 & 60 & 33 \\
\hline SK-T & $\begin{array}{l}\text { Subkultur berulang } \\
3 \mathrm{x} \text { - terang }\end{array}$ & 20 & $\left.3^{*}\right)$ & $90,0 \mathrm{a} \pm 17,4$ & 20 & 100 & $\left.13^{*}\right)$ \\
\hline SK-G & $\begin{array}{l}\text { Subkultur berulang } \\
3 \mathrm{x} \text { - gelap }\end{array}$ & 20 & $\left.6^{*}\right)$ & $52,5^{b} \pm 30,5$ & 14 & 70 & $\left.29^{*}\right)$ \\
\hline SK-AA-G & $\begin{array}{l}\text { Subkultur berulang } \\
\text { + rendam asam } \\
\text { askorbat-gelap }\end{array}$ & 20 & $\left.4^{*}\right)$ & $10^{c} \pm 3,3$ & 6 & 30 & - \\
\hline SK-SA-G & $\begin{array}{l}\text { Subkultur berulang } \\
\text { + rendam (sukrosa + } \\
\text { arang aktif)-gelap }\end{array}$ & 20 & $\left.5^{*}\right)$ & $45^{b} \pm 22,2$ & 14 & 70 & $\left.19^{*}\right)$ \\
\hline
\end{tabular}


berulang menunjukkan tidak terjadi browning hingga $50 \%$ dari total jumlah eksplan. Hasil tersebut menegaskan bahwa perlakuan perendaman dalam larutan antioksidan dan penempatan eksplan dalam ruang gelap mampu memperlambat waktu kemunculan browning. Rata-rata intensitas browning terendah dicapai pada perlakuan perendaman eksplan dalam asam askorbat yang diinkubasi di ruang gelap dan kombinasinya dengan perlakuan subkultur berulang, yaitu berturut-turut sebanyak $7,5 \%$ dan $10 \%$ dan nilai ini nyata lebih rendah daripada perlakuan lainnya. Jumlah total eksplan yang mengalami browning juga lebih rendah pada perlakuan perendaman eksplan dalam asam askorbat yang diinkubasi di ruang gelap atau dengan kombinasi subkultur berulang yaitu sebanyak 30\%. Hasil percobaan ini juga menunjukkan bahwa hampir seluruh eksplan yang diperlakukan tanpa asam askorbat mengalami browning lebih cepat dengan intensitas yang lebih tinggi.

Gambar 1 menunjukkan perbedaan waktu awal munculnya browning dengan waktu $>50 \%$ eksplan mengalami browning diantara seluruh perlakuan. Waktu awal kemunculan browning paling lama terjadi pada perlakuan perendaman eksplan dalam sukrosa+arang aktif yang diinkubasi di ruang gelap (SA-G) yaitu pada 19 HST, nilai ini tidak jauh berbeda dengan perlakuan perendaman eksplan dalam asam askorbat yang diinkubasi di ruang gelap (AA-G) yaitu pada 17 HST. Kedua perlakuan tersebut menunjukkan waktu awal browning yang lebih lama dibandingkan dengan kontrol gelap dan kontrol terang, yaitu berturutturut pada 3 dan 5 HST. Waktu $>50 \%$ eksplan mengalami browning tidak terjadi pada perlakuan perendaman eksplan dalam asam askorbat yang diinkubasi di ruang gelap (AA-G) dan kombinasinya dengan subkultur berulang (SK-AA-G), karena eksplan yang mengalami browning kurang dari $50 \%$.

Gambar 2 menunjukkan perbedaan persentase intensitas browning dan jumlah eksplan yang mengalami browning diantara seluruh perlakuan. Pada perlakuan yang mengalami intensitas browning tinggi, juga diikuti tingginya jumlah eksplan yang mengalami browning. Intensitas browning

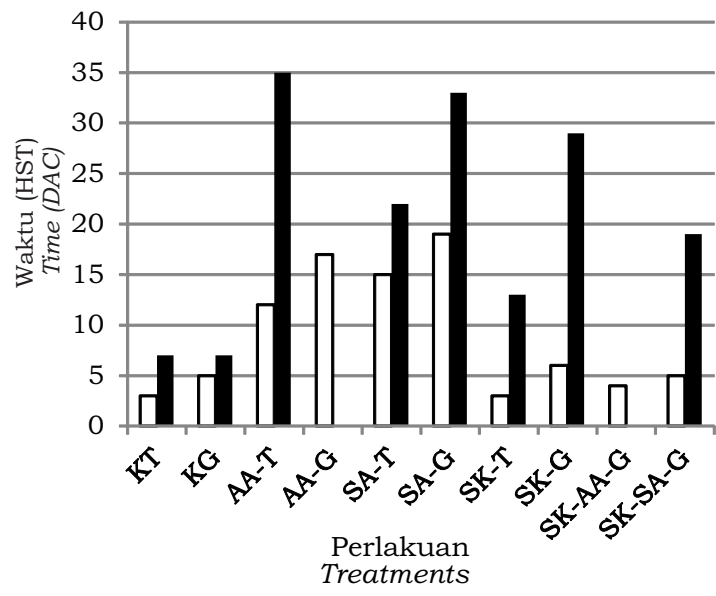

Waktu awal browning Early time of browning

- Waktu $>50 \%$ browning Time of $>50 \%$ explants browning

Keterangan (Remarks) : HST:Hari Setelah Tanam (DAC:Day After Culture), KT:Kontrol Terang (Control of Light treatment), KG:Kontrol Gelap (Control of Dark treatment), AA-T:Asam Askorbat-Terang (Ascorbic AcidLight treatment), AA-G:Asam Askorbat-Gelap (Ascorbic Acid-Dark treatment), SA-T:Sukrosa+Arang aktif-Terang (Sucrose+Activated charcoal-light treatment), SA-G:Sukrosa+Arang aktif-Gelap (Sucrose+Activated charcoal-dark treatment), SK-T:Subkultur berulang-Terang (Repeated subcultureLight condition), SK-G:Subkultur berulang-Gelap (Repeated subculture-Dark condition), SK-AAG:Subkultur berulang-Asam Askorbat-Gelap (Repeated subculture-Ascorbic acid-Dark condition), SKSA-G:Subkultur berulang-Sukrosa+Arang aktif-Gelap (Repeated subculture-Sucrose+Activated charcoal-Dark condition).

Gambar 1. Perbedaan antar perlakuan pada waktu awal browning dan waktu $>50 \%$ eksplan mengalami browning

Figure 1. Differences among treatments on early time of browning and time of $>50 \%$ explants browning 


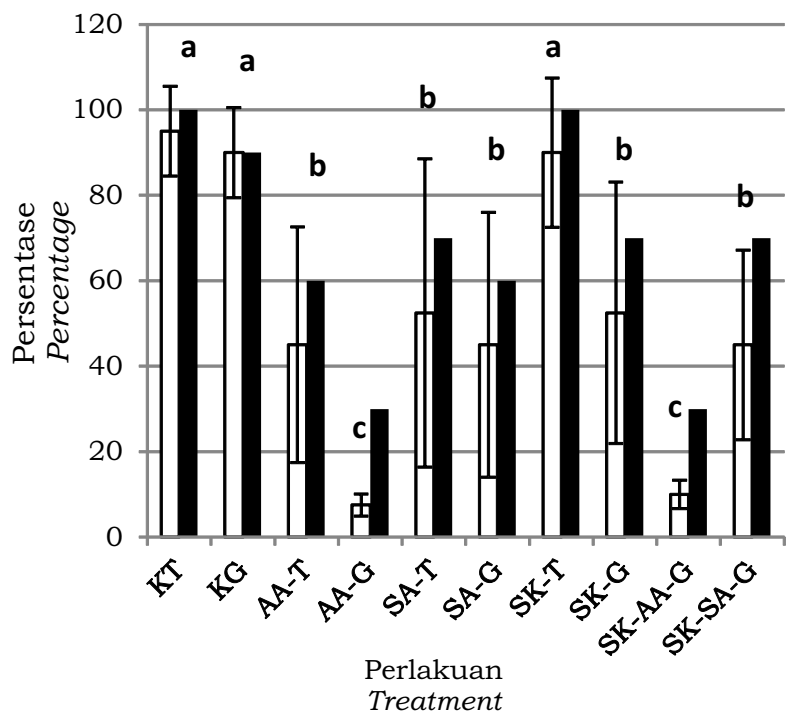

$\square$ Intensitas browning Browning intensity

- Jumlah eksplan browning Number of browning explants

Keterangan (Remarks) : HST:Hari Setelah Tanam (DAC:Day After Culture), KT:Kontrol Terang (Control of Light treatment), KG:Kontrol Gelap (Control of Dark treatment), AA-T:Asam Askorbat-Terang (Ascorbic AcidLight treatment), AA-G:Asam Askorbat-Gelap (Ascorbic Acid-Dark treatment), SA-T:Sukrosa+Arang aktif-Terang (Sucrose+Activated charcoal-light treatment), SA-G:Sukrosa+Arang aktif-Gelap (Sucrose+Activated charcoal-dark treatment), SK-T:Subkultur berulang-Terang (Repeated subcultureLight condition), SK-G:Subkultur berulang-Gelap (Repeated subculture-Dark condition), SK-AAG:Subkultur berulang-Asam Askorbat-Gelap (Repeated subculture-Ascorbic acid-Dark condition), SKSA-G:Subkultur berulang-Sukrosa+Arang aktif-Gelap (Repeated subculture-Sucrose+Activated charcoal-Dark condition). Data yang diikuti huruf yang sama tidak berbeda nyata pada taraf nyata $5 \%$ (data followed by the same letter are not significantly different at $P=0,05$ ).

Gambar 2. Perbedaan intensitas browning dan jumlah eksplan yang mengalami browning diantara seluruh perlakuan.

Figure 2. Differences among treatments on browning intensity and number of browning explants

terendah dicapai pada perlakuan perendaman eksplan dalam asam askorbat yang diinkubasi di ruang gelap (AA-G) yaitu sebanyak $7,5 \%$ dengan jumlah eksplan yang mengalami browning hanya 30\%. Hasil tersebut tidak berbeda nyata dengan perlakuan subkultur berulang+perendaman eksplan dalam asam askorbat yang diinkubasi di ruang gelap (SK-AA-G) yaitu $10 \%$ dengan nilai jumlah eksplan yang mengalami browning sama yaitu sebanyak $30 \%$. Data tersebut menunjukkan hasil yang berbeda nyata dengan kontrol terang dan kontrol gelap.

Hasil pengamatan menunjukkan perlakuan asam askorbat yang diinkubasi dalam ruang gelap menunjukkan hasil terbaik untuk keseluruhan respon. Waktu terjadinya browning yang lama (17 HST), intensitas browning lebih rendah $(7,5 \%)$, dan persentase eksplan yang mengalami browning mampu ditekan hingga 30\%. Hasil tersebut menegaskan bahwa perendaman eksplan dalam asam askorbat terbukti cukup efektif menanggulangi browning fase induksi kalus pada kultur midrib daun klon karet PB 330. Perendaman eksplan asam askorbat tidak hanya mengekspose eksplan pada senyawa reduksi tetapi juga pada $\mathrm{pH}$ rendah. Pada $\mathrm{pH}$ di bawah 4, diketahui aktivitas enzim PPO (Polyphenol Oxidase) menurun karena reduksi dari $\mathrm{Cu}^{2+}$ menjadi mononuclear copper $\left(\mathrm{Cu}^{+}\right)$pada sisi aktifnya, atau kehilangan rantai copper pada sisi aktifnya, atau berhubungan dengan reduksi senyawa quinon menjadi difenol (Arpita, Subroto, Pinaki, \& Bidyut, 2010). Pada tanaman karet, aktivitas PPO terjadi pada rentang $\mathrm{pH}$ 4-10, dengan aktivitas optimal terjadi pada pH 6 (Muhamad, Chirapongsatonkul, \& Churngchow, 2012). PPO dilaporkan terdapat pada fraksi lutoid dan partikel Frey-Wyssling yang terdapat pada pembuluh lateks, bahkan pada lutoid ditemukan hingga 5-34 kali lebih tinggi dibandingkan pada partikel Frey-Wyssling (Sakdapipanich \& Rojruthai, 2012). Seperti 
diketahui, pembuluh lateks ada di seluruh bagian tanaman karet, termasuk pada bagian midrib daun yang digunakan sebagai eksplan. (PPO) diketahui terdapat pada daun, biji dan suspensi sel dari tanaman karet Hevea brasiliensis. dimana catechol ditemukan paling banyak sebagai spesifik substratnya (Muhamad et al., 2012). Diantara inhibitor PPO yang diuji pada tanaman rambutan (Nephelium lappaceum L.), inhibitor yang efektif untuk catechol sebagai substratnya adalah asam askorbat (Haque, Al-Jassabi, Saad, \& Satyakeerthy, 2014).

Mekanisme pencegahan browning dapat dilihat pada Gambar 3. Seperti diketahui, oksigen dibutuhkan dalam aktivitas respirasi. Aktivitas respirasi dapat mengakibatkan munculnya radikal oksigen bebas, yang dapat memicu dekompartemenisasi (pecahnya vakuola dan plastida di dalam sel) yang menyebabkan aktifnya enzim PPO yang akhirnya menyebabkan pencoklatan jaringan (browning). Senyawa antioksidan berperan dalam menangkap radikal oksigen bebas se hingga mampu mencegah dekompartemenisasi yang bisa mengaktifkan enzim PPO (Veltman \& Peppelenbos, 2003). Asam askorbat berperan dalam merubah radikal tocopheryl menjadi semi-dehydroascorbic acid, sehingga tidak berperan dalam membentuk senyawa hidrogen peroksida yang bersifat toksik (Gambar 4).

Pada kultivar tanaman pir, penambahan $100 \mathrm{mg} / \mathrm{L}$ asam askorbat
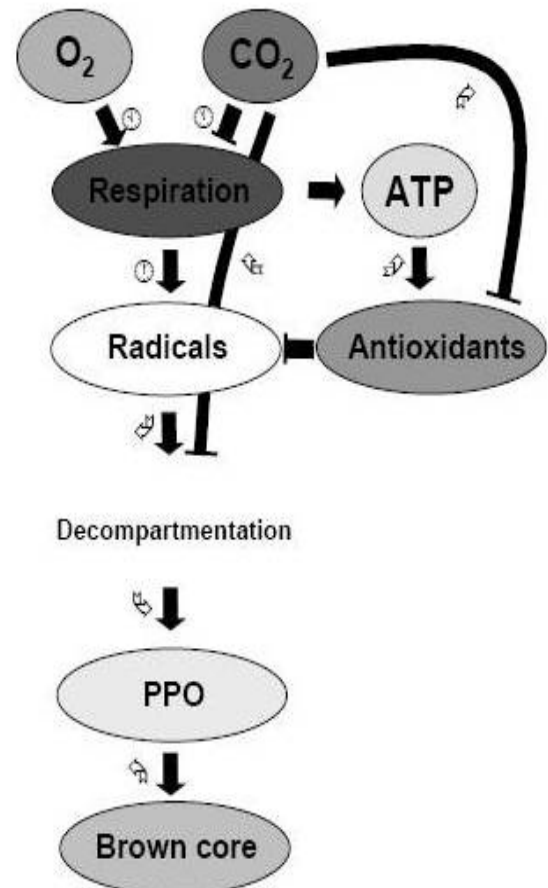

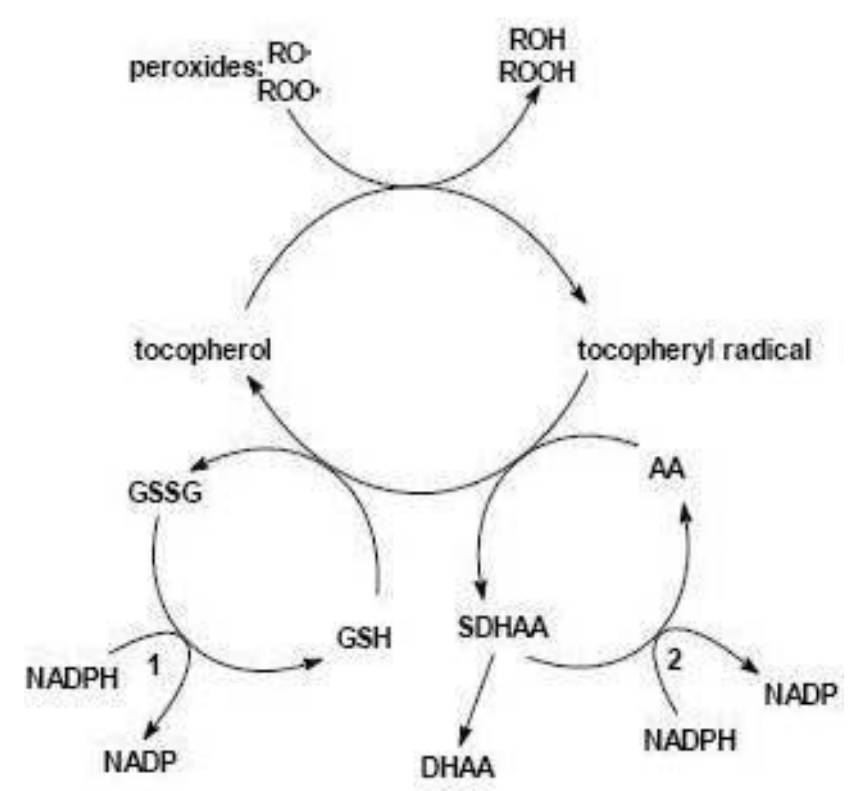

Gambar 4. Interaksi antara AA (Asam Askorbat) dan GSH (bentuk reduksi dari glutathione) dalam mengubah senyawa radikal tocopheryl.

Figure 4. Interaction between AA (Ascorbic Acid) and GSH (glutathione reduction form) on changing of radical tocopheryl. 
Tabel 4. Skor intensitas browning dari terendah hingga tertinggi

Table 4. Score of browning intensity from lowest to highest level

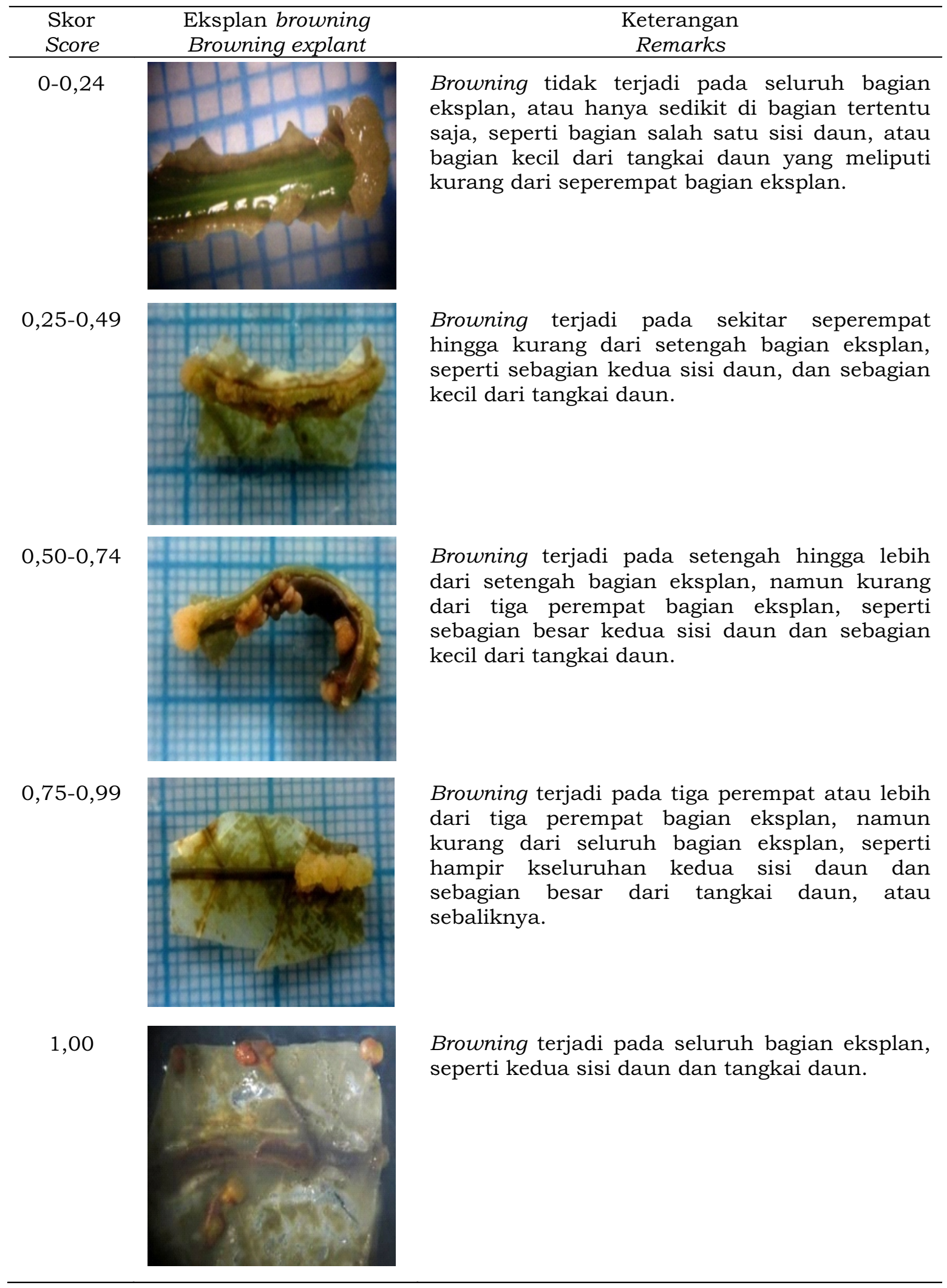


selama 15 menit sebelum sterilisasi terbukti dapat mengurangi intensitas browning (Jartoodeh, Davarynejad, Tehranifar, Kaveh, \& Bisheh, 2013). Eliminasi browning pada eksplan tanaman $B$. huillensis menggunakan bagian nodal, juga efektif digunakan $200 \mathrm{mg} / \mathrm{L}$ asam askorbat (Ndakidemi, Mneney, \& Ndakidemi, 2014). Pada tanaman leci (Litchi chinensis sonn.) pencelupan eksplan dalam asam askorbat setelah pelukaan, sangat efektif mengurangi intensitas browning, sedangkan penambahan arang aktif tidak berpengaruh. Hal tersebut diduga karena arang aktif lebih berpengaruh terhadap penyerapan nutrisi media dibandingkan penyerapan polifenol pada eksplan (Pankaj, Pandey, \& Roy, 2014). Senada dengan hasil review yang dilakukan oleh Ionita (2013) pada beberapa tanaman, urutan inhibitor yang paling efektif untuk menghambat aktivitas PPO yaitu : asam askorbat, asam sitrat, L-cysteine dan sodium metabisulfit. Hasil penelitian pada tanaman selada (Lactuca sativa L. cv 'Iceberg'), salah satu gen kunci yang berperan dalam jalur biosintesis asam askorbat, L-galactono-1,4-lactone dehydrogenase (L-GalLDH), terekspresi. Overekspresi dari $L$-GalLDH menyebabkan akumulasi asam askorbat dan mengurangi intensitas browning pada daun selada setelah dipotong. Hal ini membuktikan, adanya peran asam askorbat endogen sebagai agen pencegah browning (Landi et al., 2015).

Skoring intensitas browning disajikan dalam Tabel 4. Pada beberapa kasus, sekalipun eksplan mengalami browning pada awal waktu, namun tidak menghambat kemunculan kalus, dan ketika browning semakin meningkat kalus tidak mampu berkembang lebih lanjut yang akhirnya turut mengalami browning.

\section{KESIMPULAN DAN SARAN}

Pencegahan browning fase induksi kalus pada kultur midrib daun klon PB 330 berhasil dilakukan hingga $30 \%$ dengan intensitas browning hanya $7,5 \%$ pada perlakuan perendaman asam askorbat steril $100 \mathrm{mg} / \mathrm{L}$ selama 30 menit sebelum tanam dan kultur diinkubasi dalam ruang gelap hingga terbentuk kalus. Kalus friabel yang telah terbentuk disarankan segera disubkultur pada medium diferensiasi kalus untuk mencegah terjadinya browning susulan akibat terlalu lama berada dalam medium yang sama.

\section{DAFTAR PUSTAKA}

Arpita, S., Subroto, D., Pinaki, B., \& Bidyut, B. (2010). Inhibition of polyphenol oxidase in banana, apple and mushroom by using different antibrowning agents under different conditions. Int. J. Chem. Sci., 8(5), S550-S558. Diakses tanggal 7 Juni $20016 \quad d$ a r i www.sadgurupublications.com/Conte ntPaper/2010/62_Format.pdf

Corduk, N., \& Aki, C. (2011). Inhibition of browning problem during micropropagation of Sideritis trojana Bornm. an endemic medicinal herb of Turkey. Romanian Biotechnological Letters, 16(6), 6760-6765. Diakses tanggal 6 Juni 2016 dari www.researchgate.net/publication/2 59378783

Esmail, A. L. G., Haggag, L. F., Barakat, M. N., Farag, K. M., Zayed, N. S., \& Fouad, A. A. (2014). Direct effect of medium types, explant type and antioxidant treatments on micropropagation of Pyrus" Lecont". Middle East Journal of Agriculture Research, 3(3), 618-622. Diakses tanggal 7 Juni 2016 dari www.curresweb.com/mejar/mejar/20 14/608-622.pdf

Haque, A. M. T. E., Al-Jassabi, S., Saad, A., \& Satyakeerthy. (2014). Biochemical studies on the characters of polyphenol oxidase from rambutan (Nephelium lappaceum L.) Peel. Middle-East Journal of Scientific Research, 21(4), 623-627.doi:10.5829/idosi.mejsr. 2014.21.04.82430

Ionita, E. (2013). Plant polyphenol oxidases: isolation and characterization. Innovative Romanian Food Biotechnology, 13, 1-10. Diakses tanggal 6 Juni 2016 dari http://www.bioaliment.ugal.ro/ejour nal.html. 
Jartoodeh, S. V., Davarynejad, Gh. H., Tehranifar, A., Kaveh, H., \& Bisheh, H. A. (2013). Reducing browning problem in micropropagation of three pear cultivars; Sebri, Shekari and Natanz. Curr. Opin. Agric. 2(1), 25-27. Diakses tanggal 6 Juni 2016 dari https://www.researchgate.net/public ation/259530975

John, K. S., Bhat, S. G., \& Prasada Rao, U. J. S. $\quad\left(\begin{array}{llll}2 & 0 & 0 & 3\end{array}\right)$. B i o c h e m i c a 1 characterization of sap (latex) of a few indian mango varieties. Phytochemistry, 62(1), 13-19. doi: 10.1016/S0031-9422(02)00441-7

Landi, M., Fambrini, M., Basile, A., Salvini, M., Guidi, L., \& Pugliesi, C. (2015). Over expression of L-galactono-1,4lactone dehydrogenase (L-GalLDH) gene correlates with increased ascorbate concentration and reduced browning in leaves of Lactuca sativa $\mathrm{L}$. after cutting. Plant Cell, Tissue and Organ Culture (PCTOC), 123, 109-120. doi:10.1007/s 11240-015-0819-y

Mellidou, I., Buts, K., Hatoum, D., Ho, Q. T., Johnston, J. W., Watkins, C. B., Schaffer, R. J., Gapper, N. E., Giovannoni, J. J., Rudell, D. R., Hertog, M. L. A. T. M., \& Nicolai, B. M. (2014). Transcriptomic events associated with internal browning of apple during postharvest storage. BMC Plant Biology, 14, 328 (17p). doi:10.1186/s12870-014-0328-x

Morfeine, E. A. (2013). Effect of antibrowning on initiation phase of Musa species grand naine in vitro. Journal of Forest Products \& Industries, 2(2), 4547. Diakses tanggal 7 Juni 2016 dari research pu b.org/journal /jfpi/number/vo12-no2/vo12-no27.pdf

Muhamad, N., Chirapongsatonkul, N., \& Churngchow, N. (2012). Defenserelated polyphenol oxidase from Hevea brasiliensis cell suspension: purification and characterization. Journal Applied Biochemistry and Biotechnology, 167(1), 177-189. doi: 10.1007/s 12010-012-9690-Z
Ndakidemi, C. F., Mneney, E., \& Ndakidemi, P. A. (2014). Effects of ascorbic acid in controlling lethal browning in in vitro culture of Brahylaena huillensis using nodal segments. American Journal of Plant Sciences, 5(1), 187-191. doi: 10.4236/ajps.2014.51024

Pankaj, K., Pandey, S. K., \& Roy, K. A. (2014). Ascorbic and citric acids in combination resolve the problems encountered in micro-propagation of litchi from shoot tips. Journal of Cell and Tissue Research, 14(1), 4159. 4164. Diakses tanggal 6 Juni 2016 dari www.tcrjournals.com/tr_pastabstract .php?vid=35

Sakdapipanich, J. T., \& Rojruthai, P. (2012) Molecular structure of natural rubber and its characteristics based on recent evidence. In R. Sammour. Biotechnology, molecular studies and novel applications for improved quality of human life. (p.213-238). Rijeka Croatia: Intech.

Ru, Z., Lai, Y., Xu, C., \& Li, L. (2013). Polyphenol oxidase (PPO) in early stage of browning of Phalaenopsis leaf explants. Journal of Agricultural Science, 5 (9). 57-64. doi:10.5539/jas.v5n9p57

Veltman, R. H., \& Peppelenbos, H. W. (2003). A proposed mechanism behind the development of internal browning in pears (Pyrus Communis cv. Conference). Acta Hort, 600, 247-255. doi: $10.17660 /$ ActaHortic . 2003.600.32 